\title{
THE ANALYSIS OF EVOLUTIONARY CHANGES IN THE SYSTEM OF HIGHER MEDICAL EDUCATION IN UKRAINE IN THE FIRST HALF OF THE XX-TH CENTURY
}

\author{
Tatiana Kyryan \\ $P h D$ in pedagogical Sciences \\ Cherkassy Medical College \\ 215 Khreshchatic str., Chercassy, Ukraine, 18000 \\ tatyanakiryan@ukr.net
}

\begin{abstract}
The article is devoted to the development of the higher medical education in Ukraine in 1900-1940. The actuality of the history of educational establishments' system generalization for the theoretical understanding of educational process peculiarities within a certain brunch of education is revealed. The state of the higher medical education in Ukraine at the beginning of the XX century is depicted. The development of universities' medical departments in the first two decades of the XX century is analyzed. The common features and differences of university education in Russian and Austrian parts of Ukraine are described. Organizational forms of medical educational establishments are analyzed. The tendency of increasing the system of educational establishments by the foundation of the higher courses for women is stated. The changes in the system of medical education after the establishment of the soviet power in Ukraine are analyzed. Soviet government activities in the sphere of higher education in general and its medical branch in particular are depicted. The dynamics of medical institutes as well as the system of higher education administration development in 1920-1930-s is revealed. New organizational forms were established that reflected the search for the optimal educational system corresponding to the new epoch challenges and the goals of the new state. The influence of ideological conceptions on all branches of higher education in that time is obvious. It was especially strong in 1920-s in comparison with more pragmatic 1930-s. The general conclusion is made about the unification and strengthening of the state control in the educational process, especially in the soviet period. It is stated that, though the organs of self-administration in higher school were functioning, the educational process was to the great extent centralized. The formation of the soviet higher medical education system in Ukraine in general till the end of 1930-s is noted.
\end{abstract} Ukraine.

Keywords: educational process, the system of educational establishments, higher medical education in

\section{Introduction}

The educational process is a complex and multifaceted phenomenon that requires a comprehensive theoretical understanding. Its organizational forms, which are generated by the system of educational institutions, are the necessary part in the implementation of the educational process.Their activities should result in such educational environment, which optimally carries out didactic and instructional goals of the educational process.The process of functioning of educational institutions is the combination and interaction of educational organizations resources: human, logistical, methodological, financial.Without the analysis of education system it is impossible to create a full-fledged theoretical model of educational process. It is quite obvious for professional education, particularly medical. The analysis of the history of higher medical education system is extremely important in this context.

The medical education system in Ukraine, as elsewhere in the world, has been formed around higher educational medical institutions.The main ones are now in Ukraine medical universities and medical colleges (in the Soviet period - medical institutes and medical schools). This system began to take shape even in pre-Soviet times, and was mostly formed in the first decades of the Soviet period. That is why the time from the beginning of the twentieth century till 30-s in the history of the medical education in Ukraine requires special attention. 


\section{Analysis of literature data and problem statement}

Information concerning specified period is contained in the general work on the history of medical education in USSR [1]. This information is descriptive in nature and presents some facts from the history of medical education. Some facts about the development of medical education at Western Ukraine can be found in [2]. Biographical data and background information on the development of medicine in Ukraine are to be found in [3]. The system of higher education in Russia is analyzed in the work [4] which may be used in some aspects concerning medical education. Historical essays dedicated to the history of Kyiv medical university [5], Lviv medical university [6], Odessa medical university [7], Kharkiv medical university [8], Dnipropetrovsk medical academia [9], can be used as sources of valuable materials. There is no theoretical generalization of the problems of higher medical education in Ukraine in the specified chronological period yet which reveals general tendencies in its development and makes comparative analysis of pre-soviet and soviet periods in higher medical education.

\section{The article's aim and objectives}

The aim of the article is to identify major trends in the development of the system of higher medical education of Ukraine in the first decades of the twentieth century (in the period up to 1941).

To achieve this goal it is necessary to perform such tasks:

1. Firstly it is necessary to analyze and systematize the development of the net of higher medical establishments in Ukraine in the specified period.

2. Secondly the analysis has to be made of higher medical educational establishments' management as well as the government policy in relation to it.

3. The general tendencies are to be revealed as well as specific features of presoviet and soviet periods in the development of medical education in Ukraine.

\section{The system of higher medical education in Ukraine in 1900-1910-s}

In the early twentieth century the system of higher medical education of Ukraine consisted of the medical faculties of universities. 4 universities had been opened on the territory of Ukraine until the twentieth century: Lviv (1661), Kharkiv (1805), Kyiv (1834), Odessa (1865). Not always immediately, but in all of these schools the medical faculties were organized, that was required by the classical scheme according to which the University must include the medical faculty (along with the theological, philosophical and legal). Medical faculty in Lviv University was opened twice, in 1784 (ceased to exist in 1875 [10]) and in 1894. In Kharkiv medical faculty has been functioning since the inception of the University (1805). In Kiev University classes in medical school began in 1841. Finally, in 1900, the medical faculty of the Novorossiysky University was opened in Odessa, that was a significant event in the life of the town and has left an appreciable trace in its history [6].

Regarding the organizational forms of Ukrainian universities in the early twentieth century it must be stated that they essentially differed in the Russian and Austro-Hungarian part of Ukraine. It was common that in both parts of Ukraine universities were state institutions and their structure, powers, degree of academic freedom were completely determined by the state. In Russia in the early twentieth century the universities were actually the local units of the Ministry of national education. They were financed by the state Treasury. Universities trained doctors who, as a rule, were engaged in the public service or entered the group of government officials [4].

The university management was administered by the Department of national education of the Russian Empire Ministry of education. But its connection with educational institutions was not immediate. It passed through the office of the curator ("the trustee") of the school district, which was endowed with the broadest powers. The curator carried out the daily management of all the schools in the district. In accordance with the University Charter of 1884, "the curator of the school district cares about the welfare of the University, overseeing University teaching and precise execution by all institutions and officials belonging to the University of the rules prescribed by law or by orders of the government, he also terminates any deviation from these rules and prosecutes those who are guilty, seeks to award those who are worthy" [2]. The Institute of curators was the bureaucratic structure that often interfered in educational process in universities. Teachers complained about the extraordinary amount of paperwork that had to be prepared that distracted professors of universities from teaching [2]. Only in May of 1917 
the Commission for the reform of the institutions of higher education, established after the February revolution, approved the proposal made by the famous Ukrainian scientist V. I. Vernadsky about the exclusion of universities from the management of curators of school districts.

Rectors and professors' councils were the administrative bodies of Russian universities in the early twentieth century. The heads of medical faculties were the deans, who acted together with the faculty's professorial meetings. University Charter of 1884 significantly narrowed the rights of universities. In particular, it abolished the right of professors' councils to elect the leadership of the University and its units. Before 1905 all administrative positions, including rectors, vice-rectors, deans of faculties, were replaced by direct appointment. Only since 1905 professors' councils began to put forward the candidates for the posts of rectors and vice-rectors. Rectors were to be approved by the tsar directly, and vice-rectors by the Minister of national education. Candidates for the position of the dean of a medical faculty were nominated by faculty assemblies and were approved by the minister of national education.The powers of the university councils and faculty meetings were enlarged, but still they couldn't make a final decision in the main issues of educational process. They could only express their opinion as for academic programs and plans, amendments to them, the election of professors, the installation of the departmental structure of the university, the approval of job descriptions and internal regulations of the professorial council. The final decision which was obligatory for execution by all the university professors belonged to the minister of national education personally [2].

Organizational forms of the Lviv University medical faculty in the early twentieth century were due to the peculiarities of higher education in the Austro-Hungarian Empire. The universities in this country, unlike the primary and secondary educational institutions were directly subordinated to the Central government, in the early twentieth century it was the Ministry of education and religions of Austria-Hungary. The highest governing body of the Lviv University was the academic Senate composed of the rector, vice-rector, deans, representatives of the faculties, the secretary. The university Senate had the powers in such issues of university life as academic process, scientific work, awarding degrees, administrative cases. The restoration of the medical faculty in Lviv took place on 9 September 1894 in accordance with the Imperial decree of October 25, 1891. The opening ceremony of the faculty was attended by Emperor Franz Josef I. He also personally laid the keystone for the building of anatomy, histology and physiology departments [10]. Medical faculty of Lviv University was guided by a collegial body - the Board of professors of the faculty, which included the dean, the pro-dean, all the professors and two elected representatives from associate professors. There were no departments in the modern sense of the word; the concept of the department was connected with the personality of a professor who gave a course of lectures. However, the University had academic institutions or institutions that correspond roughly to the modern concept of the department or office. In institutions there were practical and seminar classes, they had permanent apartments, equipment, libraries and staff [6].

University education in Ukraine in the 19-tn century was designed for men. Only in exceptional cases women were admitted as students of free university courses. But in the early twentieth century the development of higher medical education of women began, which subsequently played a significant role in expanding higher medical education of Ukraine. In 1907, in Kyiv a medical department at the higher courses for women with a university training program was opened. The department was headed mainly by professors and associate professors of the medical faculty of the Kyiv University. 295 women were the first trainees of the department. At the end of 1916 the permission was obtained to create in Kiev the Women's medical Institute, the first Director of which was professor I. P. Morozov.

In Kharkiv in 1908 the medical faculty at the private University for women was opened. But two years later it ceased functioning because of the lack of a base for clinical training. Despite of this, on January 30, 1911, the women's medical Institute was founded. It was headed by the outstanding physiologist V. Y. Danilevsky. The first 242 graduates finished the study in February 1914. In 1910, in Odessa the higher women's medical courses were opened with the active participation of the professors B. F. Verigo, N. K. Lysenkov, which gave medical education according to the program of a university medical faculty. Finally, in 1916 the higher courses for women were opened in Ekaterinoslav with its medical department (about 900 students). The dean of this department was the professor V. I. Tomashevsky. Lectures were read mostly by professors of the Kharkiv University [1]. Thus, 
another four women's higher medical educational institutions (in Kiev, Kharkov, Odessa and Ekaterinoslav) were added to the recent four medical faculties in the universities of Ukraine before 1917.

\section{The system of higher medical education in Ukraine in 1920-1930-s}

Political changes in Ukraine in 1917-1920, had affected the system of higher medical education. The initial management of higher educational institutions in Soviet Ukraine was transferred to People's Commissariat of education (Narcomos), which was formed in January 1919. Higher educational institutions (unlike schools) were guided directly by Narcomos. In 1920 the Main Committee for professional-technical and socio-scientific education was formed at the People's Commissariat of Ukrainian Soviet Republic, which was supervising higher education institutions.

In 1930, there have been changes in the guidance of medical higher educational establishments of Ukraine. Higher medical and pharmaceutical education was transmitted from the system of People's Commissariat of education to the system of the People's Commissariat of health. It was thought that this, above all, would allow greater use of medical institutions as the clinical base of medical education. In addition, there had to be improved conditions for the development of medical science in higher education. The People's Commissariat of education of the USSR retained the functions of the common-ideological, scientific and methodological guidance of the public education system in accordance with the decree of the Central Executive Committee and the Council of People's Commissarsof the USSR (13.08.1930).

The creation in 1934 of the Main Directorate of medical education institutions in the structure of people's Commissariat of health of the USSR may be considered as a step towards further specialization of the state governance of the higher medical education sector. In 1936 the Committee on higher education at the Council of People's Commissarsof the USSR was formed, which carried out the general management of the higher education of Ukraine.

From the very beginning of its activities, the governing bodies of higher education in the Soviet Ukraine had shown a commitment to the creation of higher medical educational institutions of a new type. In 1920 the universities were abolished, and their faculties were reformed into the higher education institutes with transfer to them the entire property complex, personnel and funding [11]. The medical faculties of the universities were transformed into medical academies. Such academies have been established in Kharkiv, Ekaterinoslav (Dnipropetrovsk), Odessa through associations of medical faculties and the higher women's courses.In Kyiv in 1920 the National Institute of health was established on the basis of the medical faculty, the women's medical Institute and the medical faculty of Ukrainian state university, in 1921 it also received the name of the medical Academy. Academies in Kharkiv, Odessa and Ekaterinoslav consisted of one faculty, in Kyiv of the three: medical, dental and pharmaceutical. At the Kharkiv Academy dental College and chemical-pharmaceutical Institute were opened.

New educational institutions did not have sufficient material and human resource base. They had not enough apartments; the teaching staff was not fully completed. Management of academies has been assigned to the professorial boards, which didn't quite satisfied the Soviet leadership, for they consisted mainly of the representatives of the old pre-revolutionary higher education. Later elected boards were established in academies, which were supplemented by committees of the representatives of teachers and students. The temporary nature of such an organization in higher medical schools is obvious. Besides, in the early 20 -ies there was no general statute for all medical schools. Each Academy operated on the basis of self-developed interim provisions.

In December 1921, Kyiv, Kharkiv, Odessa and Ekaterinoslav medical academies were converted to the corresponding institutes. In 1920-1921, in Kharkiv, Odessa and Kyiv the chemical-pharmaceutical institutes were established. Continuing the formation of a new system of higher education, in 1922 the all-Ukrainian Central Executive Committee approved the "Provisional regulations on higher educational institutions of the USSR", which applied to all institutions of higher education. In connection with this provision, the management of the medical institutes was carried out by the boards of these institutes. The people's Commissariat of the Ukrainian Soviet Republic appointed the rector and a political Commissioner of an institute from the members of its board. The bureaus of board members, trade union and the People's Commissariat for education 
representatives were established as consultative bodies. The departments' management was laid on their heads, who collaborated with subsidiary bodies, faculty committees, consisted of the heads of subject commissions and the representatives of the University community and students. Subject committee was engaged in teaching work. They united within the faculty the teachers of similar disciplines. Thus, the management of medical institutes in Ukraine had undergone considerable centralization, was largely subordinated to the governing state bodies in the field of education. In addition, it was put under strict political control of the government.

The ideological orientations of the Soviet power in 20-ies of XX century directly influenced the development of the system of higher medical education in Ukraine. A new social order, which rapidly had to be built in the Soviet Union was supposed to end with all the flaws of the old society, including, diseases. The main objective of health care should be preventive work among the working masses, the maintenance of sanitary conditions for a healthy lifestyle. It was considered that the role of the sanitary-preventive activity in a socialist society would rise in comparison with the lessening of the role of disease treatment. Hence special attention was paid to sanitary and hygienic education, as well as its preventive component, which finally acquired in the USSR a certain bias in the educational process.This was especially evident in the late 20's and early 30-ies. In 1930, Golovprofos (General Directorate of professional education) of the USSR made directive, stating that "the synthesis of clinic and prevention cannot be broken; the doctor may not be a healer without being at the same time a disease preventer. Disease prevention, clinical teaching remains the main task of higher education" [1]. Realizing this setting, the all-Ukrainian meeting on health (1930) took a decision about necessity to create in medical institutes medical-preventive, sanitary-hygienic, odontology (dental) faculties, as well as a faculty of motherhood and childhood [2].

In the same year in Kyiv, Kharkiv, Odessa, Dnipropetrovsk medical institutes sanitary-hygienic faculties and departments of maternal and child health were opened. Besides them, there were treatment-and-prophylactic and odontologic (dental) faculties. Medical-prophylactic faculty trained doctors-prophylaxians with wide profile without any specialization. Duration of training on hygiene and dental faculties were established in four years, on others four and a half years.

Another false idea, which was inculcated in the higher education of the USSR in the early 30 -ies, was the idea of possibility to combine study with production. It also answered the thoughts of the founders of communism that had become landmarks in the process of building the new society. It means not correspondence courses, which are carried out without any interruption of professional activities, but full-time, direct training in the process of performing one's professional duties. In 1931 the People's Commissariat of health of the USSR adopted a decision that "each health care organization should be used for medical training" [1]. In all large cities of Ukraine there were created hospitals-educational centers. In particular, in 1931 they were created in Kyiv, Kharkiv, Odessa, Dnipropetrovsk, Vinnitsa, Poltava, Kirovohrad, Kherson, Mykolaiv, Kremenchug, Zaporizhzhya, Melitopol, Zhytomir, in 1932 - in 8 cities more. Very quickly the ineffectiveness of the learning in the workplace became apparent. The educational process was not provided with neither sufficient teachers nor teaching materials, it hadn't ordered forms and methods, not to mention the inability to provide a high enough level of teaching non-professional disciplines. New establishments didn't give a genuine higher medical education. Already in 1934, almost all hospital-educational centers were closed. The last ones of these medical institutions were closed in 1936, and in their place the 2-nd Kharkiv and the 2-nd Kyiv medical institutes were created.

The network of medical institutions had expanded not only by opening new institutes in Kharkiv and Kyiv. In 1930 the medical institute in Stalino (Donetsk) was opened. In 1934 the correspondence Vinnitsa medical institute was established, and it was transformed into stationary soon. In 1939, a network of medical schools of the Soviet Ukraine joined the Lviv medical institute. It was created on the basis of the medical faculty of Lviv University after the annexation of the Western Ukraine. Parts of the Lviv medical institute included two faculties: medical and pharmaceutical. Thus, the number of medical schools in Ukraine had reached 14. Among them there were medical institutes in Kharkiv (two institutes), Kyiv (two institutes), Lviv, Odessa, Dnepropetrovsk, Stalino (Donetsk), Vinnytsia; dental institutes in Kharkiv and Kyiv; the pharmaceutical institutes in Kharkiv, Dnipropetrovsk, Odessa. 


\section{Results and discussion}

The result of represented analysis is a holistic picture of the relevant aspects of the changes in the system of higher medical education in Ukraine at the first four decades of the XX-th century. This picture is grounded on the relevant factual base concerning the development in organizational structure, geography, functions, state governance, dynamics of medical education which may be regarded as an advantage of the research. The result which has been achieved may be useful for the further reconstruction of the history of higher medical education in Ukraine. It may be used as well in educational process in higher medical schools. It is the beginning of the more general survey of historical aspects of medical education.

\section{Conclusions}

The conclusions to be made are the following:

1. As for the development of the net of higher medical establishments in Ukraine in the specified period it must be stated that the system of higher medical education in Ukraine was developed in the XVIII-XIX centuries. It was formed by the medical faculties of universities in Lviv, Kharkiv, Kyiv and Odessa. For the first two decades of the twentieth century, the number of medical faculties of universities in Ukraine has not changed, but there was a new type of higher medical educational institutions - higher women's courses. In 20-ies in place of medical faculties of the universities and courses for women medical institutes appeared. Their number gradually increased (new institutes in Dnipropetrovsk, Donetsk, Vinnytsia). There were also pharmaceutical and dental educational institutes.

2. Tracing the organizational forms of medical education during the first decades of the twentieth century, we can note the trend towards their unification and the strengthening of state control over the educational process, especially in the Soviet period.

3. In the 20-30-ies of the twentieth century, the medical education system in Ukraine had undergone significant changes according to significant political and socio-economic changes in society. Although in higher educational establishments the organs of self-management were kept, but the whole educational process had been centralized.

\section{References}

[1] Kryshtopa, B. P. (1985). Vyssheye meditsynskoye obrazovaniye v Ukrainskoy SSR. Kyiv: Zdorovya, 320 .

[2] Klos, L. Ye. (2002) Rozvytok medychnoyi osvity na zahidnoukrayinskyh zemlyah (druga polovyna XVIII - 30-ti roky XX st.). Kyiv, 20.

[3] Ganitkevich, Ya. V. (2004). Istoriya ukrayinskoyi medytsyny v datah ta imenah. Lviv, 368.

[4] Ivanov, A. Ye. (1991). Vysshaya shkola Rossii v kontse XIX - natchale XX veka. Moscow, 392.

[5] Onyshchenko, O. S., Honcharuk, Ye. H. (2001). VS337 160 rokiv Natsional'nomu medychnomu universytetu imeni O. O. Bohomol'tsya (1841-2001). Kuiv: Stolittya, 366.

[6] Lvivskyi universitet. Istoriya universitetu. Available at: http://www.lnu.edu.ua/about/university-today-and-tomorrow/ history/

[7] Odeskyi derzhavhyi medychnyi universitet (2010). Odesa, 53.

[8] Tsyhanenka, A. Ya. (Ed.) (2005). FPU \#2495 Kharkivs'kyy derzhavnyy medychnyy universytet, 1805-2005. Kharkiv: Kontrast, 752.

[9] Dzyak, H. V. (Ed.) (2001). Dnipropetrovs'ka derzhavna medychna akademiya, 1916-2001. Dnepropetrovsk: RVA «Dnipro-VAL», 816.

[10] Zimenkovs'kyy, B. (Ed.) (2009). L'vivs'kyy natsional'nyy medychnyy universytet im. Danyla Halyts'koho. Rik zasnuvannya 1784. Lviv: Nautilus, 412.

[11] Lisovyy, V. M. (Ed.) (2010). Vydatni vykhovantsi Kharkivs'koyi vyshchoyi medychnoyi shkoly: biobibliohr. dovid. Kharkiv: KhNMU, 207. 